\title{
Relevance of Yoga in Present Days
}

\author{
Dnyaneshwar Kantaram Jadhav* \\ Kaychikitsa department, Shri Dhanwantri Ayurvedic Medical College \& Research Centre, India
}

Submission: May 15, 2018; Published: October 23, 2018

*Corresponding author: Dnyaneshwar Kantaram Jadhav, Assistant Professor, Kaychikitsa department, Shri Dhanwantri Ayurvedic Medical College \& Research Centre, India; Tel: 8451834859; Email: dj85015@gmail.com

\begin{abstract}
India has given lot of valuable contribution to the world. Yoga is one of them. Since 2015 international yoga day is celebrated with great aplomb throughout the world. People are making it a part of their life. All this itself speaks volume about the popularity of yoga in present day. Yoga is most popular medical stream which include asana, physical stretches, breathing exercise and technique to relax and focus the mind. Modern research and facilities bring us toward luxury life, at the same time we are losing peace of mind. This loosing peace of mind inviting variety of lifestyle disease. Yoga is most useful way to bring life toward peace of mind.it is also useful in therapeutic purpose for disease like obesity, diabetes, and hypertension. Unfortunately, now days many untrained people enter in yoga teaching. Learning yoga from untrained coach should be harmful to health. All asana performed under guidance of trainer only. Indication and contraindication of all asana and yoga is also important. If yoga done in scientific ways than we only get its benefits and yoga will become more popular at national as well as international level.
\end{abstract}

Keywords: Yoga; Importance; Present day

\section{Introduction}

Yoga is group of physical, mental and spiritual practise or discipline which originated in ancient India [1]. According to rigveda, origin of yoga is pre-vedic era. Swami vivekananda also said benefit of yoga throughout of his life.

\section{Nirukti of yoga [2]}

According to Panini, the term yoga can be derived from either two roots yujir yoga or yuj sam-dhatu.

\section{Paryaya of yoga}

In Amarkosha, mentioned following paryayi words for yoga as- sanyog, dhan, yukti, sangti, anad, moksha.

\section{Definition of yoga [3]}

1. Patanjali yog darshana defined yoga as controlling chittawrutti of mana (mind).

2. According to maharshi charak, controlling on all sense organ and gain happiness can be possible due to yoga only.

3. According to kanthaponishda, controlling on all organ is called as yoga.

4. According to kaiwalyopanishada, developing soul power with help of sadhana, bhakti, dhan is called as yoga.

\section{Benefit of yoga}

1. Improves flexibility

2. Increased blood flow

3. Perfect posture
4. Improve bone health

5. Builds muscular strength

6. Drains lymph's and boosts immunity

7. Helps one to focus

8. Improve balance

\section{Yoga and karma relation [4]}

Ashtanga yoga is way of increasing skill of all karma (work). Ultimately its way of moksha. Good karma with yoga combine give moksha.

\section{Currrent status of yoga}

Now days yoga become popular. Everyone accepts the benefits of yoga. Ramdev-baba like people bring yoga word at international level.in short we can say that its beginning of golden days of yoga.

Due to its popularity, many untrained people entering in this filed, and started yoga teaching. Such people teach only aasana on name of yoga. In that flow we all are forgetting that yoga is made with eight anghas- yama, niyam, asana, pranayama, pratyahar, dhan, dharna, Samadhi respectively. Only doing aasana is like eating only rice on name of dal-rice. If we do all eight yoga than we will get its real benefit. Ayush department also accept its importance and included as one separate branch of health science.

\section{Conclusion}

Yoga is key of physical and mental peace. Due to its benefit, it's becoming more popular. But at the same time, some untrained 
people entering \& teaching yoga, which is harmful for society. If yoga can teach from well train person than we will get its all benefits. If such happen than, yoga will be popular at national as well as international level.

\section{References}

1. https://en.m.wikipedia.org/wiki/yoga

This work is licensed under Creative Commons Attribution 4.0 License

DOI: 10.19080/JYP.2018.06.555692
2. Dasgupta, Surendranath (1975) A history of Indian philosophy, Motilal banrasidass, Delhi, India, p: 226.

3. Vd.Vijay patrikar, Sampurna swasthawritta vidnyan (2005), ( $\left(1^{\text {st }}\right.$ edn), Godawai publication, Nagpur, India, pp: 5-6.

4. Dr. Akshay bhoir, Karmachi dnyaneshwari (2017) Mazhi yog sadhana ani karmacha ghol, (1 $1^{\text {st }}$ edn), Granthali publication, India, p: 59.

Your next submission with Juniper Publishers
will reach you the below assets
- Quality Editorial service
- Swift Peer Review
- Reprints availability
- E-prints Service
- Manuscript Podcast for convenient understanding
- Global attainment for your research
- Manuscript accessibility in different formats
( Pdf, E-pub, Full Text, Audio)
- Unceasing customer service
Track the below URL for one-step submission
https://juniperpublishers.com/online-submission.php

